\title{
Oerskovia turbata
}

National Cancer Institute

\section{Source}

National Cancer Institute. Oerskovia turbata. NCI Thesaurus. Code C86623.

A species of aerobic, Gram-positive, rod shaped bacteria assigned to the phylum Actinobacteria. This species is yellow with extensively branched vegetative hyphae without an aerial mycelium which breaks into motile rod shaped elements, is catalase positive, reduces nitrate, hydrolyzes casein, gelatin and starch, is not acid-fast, mesophilic, utilizes acetate, lactate, and pyruvate. O. turbata is found in soil and rarely causes infections in humans. 